Annija Kārkliṇa, Dr. iur.

Latvijas Universitātes Juridiskā fakultāte, Latvija

Jānis Kārkliņ̌̌, Dr. iur.

Latvijas Universitātes Juridiskā fakultāte, Latvija

\title{
DARBINIEKA ATSTĀDINĀŠANA NO DARBA UN TĀS TIESISKĀS SEKAS
}

\section{EMPLOYEE'S SUSPENSION FROM WORK AND ITS LEGAL CONSEQUENCES}

\begin{abstract}
Summary
Section 58 of the Republic of Latvia Labour Law provides for the right of an employer to suspend an employee from work in certain cases. Given that employee's suspension involves certain legal consequences, an employer has a duty to comply with precise preconditions for the legal and justifiable suspension of an employee. The law lays down preconditions, such as the presence of alcohol, drugs or toxic intoxication, and more general preconditions for the suspension of an employee, - cases when failure to suspend an employee from work may be detrimental to his or her safety or the health or safety of third parties. The law also provides for the legitimate interests of employer or third parties as a precondition for suspension. The aim of this paper work is to analyse the legal meaning of Section 58 of the Labour Law, case law and doctrine. The research is carried out in order to provide precise identification and general criteria when the suspension by an employer would be legal and when it would be considered as implemented without observing the purpose and meaning of the law.
\end{abstract}

Atslēgvārdi: Darba likums, darbinieka atstādināšana, darba devēja pamatotās intereses, trešo personu pamatotās intereses, atstādināšanas kārtỉba, atstādināšanas rỉkojums

Keywords: Labour Law, suspension of employee, well-founded interests of employer, well-founded interests of third-party, order of suspension, injunction of suspension

\section{Ievads}

Darba likumā (turpmāk - DL) ${ }^{1}$ atstādināšanas institūta tiesiskais regulējums ir ietverts 16. nodal̦as "Darba kārtība un darba devēja rīkojumi” 58. pantā, kurā tiek noteikta atstādināšanas institūta būtība, atstādināšanas termiṇi un ieskicēti darba devēja pienākumi un procesuālie aspekti, kas darba devējam jāievēro darbinieka atstādināšanā.

DL 58. pants nosaka darba devēja tiesības un noteiktos gadījumos arī pienākumu atstādināt darbinieku no darba. DL 58. panta pirmā daļa noteic: "Atstādināšana no

1 Darba likums: LV Likums. Latvijas Vēstnesis, 2001. 6. jūlijs, Nr. 105 (2492). 
darba ir ar darba devēja rakstveida rīkojumu noteikts pagaidu aizliegums darbiniekam atrasties darba vietā un veikt darbu, par atstādināšanas laiku viņam neizmaksājot darba samaksu." Tātad atstādināšanu raksturo trīs elementi: tā veicama tikai uz rakstveida darba devēja rīkojuma pamata, tai ir pagaidu raksturs, un par atstādināšanas laiku darbinieks nesañem darba samaksu. N̦emot vērā, ka darbinieka atstādināšana saistìta ar noteiktām tiesiskām sekām, darba devējam ir pienākums ievērot precīzus priekšnoteikumus, lai atstādināšana būtu tiesiska un pamatota. Likums kā priekšnoteikumus darbinieka atstādināšanai paredz gan konkrētus iemeslus, piemēram, atrašanos alkohola, narkotiku vai toksiska reibuma stāvoklī, kā arī vispārējus jēdzienus - kad darbinieka neatstādināšana no darba var kaitēt viṇa paša vai trešo personu drošỉbai un veselībai, kā arī darba devēja vai trešo personu pamatotām interesēm.

Šì raksta mērḳis ir analizēt DL 58. panta tiesisko sastāvu, tiesu praksi un doktrīnu, lai precīzi identificētu gadījumus un sniegtu vispārīgus kritērijus, kad darba devēja veiktā atstādināšana būtu tiesiska un kad tā notikusi, neievērojot likuma mērḳi un jēgu. Kā liecina prakse, nereti darba devēji nepareizi izprot atstādināšanas no darba mērḳi un nozīmi un nepamatoti asociē to ar soda veidu vai kā dỉkstāvi jeb darba nedošanu.

\section{Darbinieka atstādināšana kā darba devēja subjektīvā tiesība}

Uz tiesiskā kārtā noslēgtu darba līgumu ir attiecināmi tie paši līgumisko tiesību pamatprincipi kā uz ikvienu citu civiltiesisku līgumu, proti, atbilstoši Civillikuma ${ }^{2}$ 1587. pantam katrs tiesīgi noslēgts līgums uzliek līdzējam pienākumu izpildìt apsolìto, un ne darījuma sevišķais smagums, ne arī vēlāk radušās izpildīšanas grūtỉbas nedod vienai pusei tiesību atkāpties no līguma. Savukārt Civillikuma 1588. pants noteic, ka viena puse nevar atkāpties no līguma bez otras piekrišanas pat arī tad, ja pēdējā to neizpilda, un tādēl, ka viṇa to neizpilda.

Darbinieka atstādināšanai kã darba devēja rīcībai ir tieša un tūlitēeja ietekme uz darba līguma saistošo spēku, citiem vārdiem, - tas ir likumā noteikts iznēēmums no līguma saistošã spēka principa. N̦emot vērā, ka darbinieka atstādināšana ir izñēmums no ligguma vispārējā spēka principa, tā var notikt tikai īpašos likumā noteiktos gadījumos, turklāt tās izpratne nedrīkst būt pārāk plaša, kas tādējādi izjauc Darba likumā noteikto lïdzsvaru starp darba devēja un darbinieka tiesībām un pienākumiem.

No privāttiesību teorijas viedokḷa darbinieka atstādināšana ir darba devējam piemìtošas subjektīvas tiesibas, kuras pastāv uz objektīvo tiesību pamata un kuras izlietošana ir atkarīga no subjekta paša gribas ${ }^{3}$. Tādējādi, lai darbinieka atstādināšana būtu tiesiska, tās pamatā ir jābūt ievērotām objektīvām tiesību normām jeb DL 58. panta noteikumiem. N̦emot vērā, ka darbinieka atstādināšana notiek ar vienpusēju darba devēja gribas izteikumu (rīkojumu), atstādināšana ir darba devēja konstitutīvo subjektīvo tiesību īstenošana, saskaṇā ar kuru vienpusējā kārtā notiek esošā tiesiskā stāvokḷa izmaiņas. Tas nozīmē, ka, atstādinot darbinieku, darba devējs tieši un nepastarpināti izveido jeb konstituē jaunu tiesisko realitāti, izmainot tiesisko attiecību (saistību)

Latvijas Republikas Civillikums: LV Likums. Valdības Vēstnesis, 1937. 26. februāris, Nr. 46.

Balodis K. Ievads Civiltiesībās. Riga: Zvaigzne ABC, 2017, 117.lpp. 
saturu starp darba devēju un darbinieku. N̦emot vērā, ka atstādināšana ir vienpusēja subjektīvo tiesību īstenošana, adresāta piekrišana, lai rastos jaunais tiesiskais stāvoklis, nav nepieciešama, tam ir jāsamierinās ar viņa tiesiskajā sfērā notikušajām izmaiņām. Konstitutīvo subjektīvo tiesību īstenošanas tiesiskās sekas iestājas automātiski, līdzko izteikta griba ${ }^{4}$, un darba devējam pat darbinieka iebildumu gadijumā nav nepieciešams vērsties tiesā, lai panāktu jaunradītā tiesiskā stāvokḷa atzīšanu.

Augstākā tiesa ir atzinusi, ka atstādināšana no darba ir darba devējam atvēlēts preventīvs līdzeklis iespējama interešu apdraudējuma novēršanai un ka atstādināšana no darba nav disciplinārsods par kādu konkrētu pārbaudītu un pierādītu darbinieka pārkāpumu. ${ }^{5}$

\section{Darbinieka atstādināšanas likumiskie priekšnoteikumi}

Kā jau iepriekš minēts, galvenais tiesību avots darbinieka atstādināšanai ir DL 58. panta pirmā daḷa, kas nosaka, ka atstādināšana no darba ir ar darba devēja rakstveida rīkojumu noteikts pagaidu aizliegums darbiniekam atrasties darba vietā un veikt darbu, par atstādināšanas laiku neizmaksājot darba samaksu. Minētā panta daļa vien sniedz atstādināšanas legāldefinīciju, taču DL 58. panta turpmākās daļas nosaka vairākus priekšnoteikumus, kuriem jāiestājas, lai atstādināšana būtu pamatota un tādējādi arī tiesiska.

Pirmkārt, DL nodala divus atstādināšanas gadījumus:

1) darba devēja pienākums atstādināt darbinieku;

2) darba devēja tiesība atstādināt darbinieku.

Atstādināšana kā darba devēja pienākums tiek noteikta DL 58. panta otrajā dalāā, kura paredz, ka "darba devējam ir pienākums atstādināt darbinieku no darba, ja normatīvajos aktos noteiktajos gadijjumos pieprasa attiecīgi pilnvarota valsts institūcija”. Normatīvie akti nedefinē "attiecīgi pilnvarotas valsts institūcijas" saturu, taču ar to būtu saprotama ikviena publisko tiesību atvasināta persona, kurai ar likumu ir skaidri pieškuirtas tiesības iejaukties privātautonomijas jomā un pieprasīt izmaiṇas pušu privāttiesiskajās attiecībās - atstādinot darbinieku, nerēķinoties ar darba devēja gribu. Ne katra institūcija ir apveltīta ar šādām tiesībām, tāpēc, saṇemot šādu pieprasījumu, darba devējam ir jāpārbauda, vai tas ir tiesiski pamatots, t. sk. ievērojot likuma atrunas principu. Visbiežāk ar šīm institūcijām saprotamas tiesībaizsardzības iestādes, piemēram, policija, prokuratūra. Darba devējam nav pienākuma pārvērtēt institūcijas sniegto rīkojumu un tā faktologisko pamatojumu, tāpat darba devējs neuzṇemas atbildỉbu, ja institūcijas dotais rīkojums vēlāk izrādījies prettiesisks. Šādos gadījumos personai būtu tiesības no attiecīgās iestādes san,emt normatīvajos aktos noteikto kompensāciju. ${ }^{6}$

Ibid., 130. lpp.

5 Sk. Latvijas Republikas Augstākās tiesas Senāta 2010. gada 27. oktobra spriedums lietā Nr. SKC816/2010, Latvijas Republikas Augstākās tiesas Civillietu departamenta 2017. gada 9. janvāra spriedums lietā Nr. C28410609 SKC-461/2017 (8. p.).

6 Sk. Kriminālprocesā un administratīvo pārkāpumu lietvedībā nodarītā kaitējuma atlīdzināšanas likums: LV Likums. Latvijas Vēstnesis, 2017. 19. decembris, Nr. 252 (6079). 
Savukārt darba devēja tiesības atstādināt darbinieku ir paredzētas DL 58. panta trešajā daḷā. Šìs normas formulējums ir abstraktāks, tāpēc arī praksē ir radījis vairākas interpretācijas. No šìs panta daļas izriet, ka darba devējam ir tiesības atstādināt darbinieku šādos gadījumos:

1) darbinieks, veicot darbu vai arī atrodoties darba vietā, ir alkohola, narkotiku vai toksiska reibuma stāvoklī,

2) darbinieka neatstādināšana no darba var kaitēt viṇa paša vai trešo personu drošỉbai un veselïbai,

3) darbinieka neatstādināšana no darba var kaitēt darba devēja vai trešo personu pamatotām interesēm.

Par pirmo gadījumu norādāms, ka praksē ir sastopami strīdi par to, ko tieši aptver jēdziens “alkohola, narkotiku vai toksiska reibuma stāvoklis”. Lai arī DL nesniedz jēdziena "reibuma stāvoklis" definīciju, kā arī nenosaka reibuma stāvokḷa noteikšanas kritērijus, nav šaubu, ka nav izmantojami kritēriji, kas noteikti autovadītājiem kā speciāliem tiesību subjektiem ceḷu satiksmē. Priekšnoteikums atstādināšanai ir fakts reibuma stāvoklis ${ }^{7}$, ko darba devējs var konstatēt ar jebkuriem Civilprocesa likuma 17. nodaḷā paredzētajiem pierādīšanas līdzekḷiem (ar paša darbinieka paskaidrojumu, ar attiecīga akta sastādīšanu, ar liecinieku liecībām, ar medicīnas darbinieku atzinumu, ārstu ekspertīzes atzinumu u. c.) ${ }^{8}$. Fakts vien, ka mēraparāts vai ārsts darbinieka asinīs ir konstatējis alkoholu, nav priekšnoteikums darbinieka atstādināšanai, ja darbinieks neatrodas reibuma stāvoklī. Reibuma stāvoklis ir tāds stāvoklis, kad pārbaudāmās personas (darbinieka) ārējais izskats un uzvedība liecina par izmain̄ām, salīdzinot ar viṇa ierasto stāvokli darba vietā, viņš nepilnīgi orientējas apkārtējā vidē, ir palēnināta reakcija, neadekvāta uzvedỉba un komunikācija, grīḷiga gaita, uzbudinājums u. tml. Arī Augstākās tiesas Senāts 2012. gada 24. augusta spriedumā lietā Nr. SKC-1041/2012, konstatējot pārbaudāmās personas ārējo izskatu, norādījis, ka darbinieka izelpā konstatētais alkohola daudzums 0,09 promiles neliecina nedz par viņa atrašanos alkohola ietekmes, nedz alkohola reibuma stāvoklī. N̦emot vērā iepriekš minēto, secināms, ka, pēc DL 58. panta trešās daḷas noteikumiem, atstādināšanas pamats ir darbinieka reibuma stāvoklis, kas darba devējam ir rūpīgi jāfiksē, bet ne pats fakts vien, ka darbinieka izelpā tiek uzrādītas promiles.

Lielākie strīdi un neskaidrības darbinieku atstādināšanas kontekstā ir saistāmas ar otrajā un trešajā punktā norādītajiem gadijjumiem, kuri satur jēdzienus noteiktu personu drošības, veselības un pamatotās intereses. Šie DL 58. panta trešajā daḷā noteiktie atstādināšanas priekšnoteikumi ir veidoti tā, ka darba devējam ir nepieciešams vērtēt situācijas tālāko varbūtējo attīstību, t. i., vai neatstādināšana jeb atḷaušana turpināt darbiniekam veikt darbu un/vai atrasties darba vietā neradīs negatîvas tiesiskas vai mantiskas sekas. Kā negatīvās sekas primāri tiek norādītas paša darbinieka vai trešo personu drošība un veselība, bet tālāk pieminētas arī darba devēja vai trešo personu pamatotās intereses. Jēdzieni “personu drošība un veselība” ir piemēra veidā

Darba likums ar komentāriem. Zvērinātu advokātu birojs "BDO Zelmenis \& Liberte” Rīga: LBAS, 2010, 195. lpp.

8 Latvijas Republikas Augstākās tiesas Civillietu departamenta 2014. gada 19. novembra spriedums lietā Nr. SKC-2712-14, 7.1. p. 
nosaukti iespējamie apdraudējuma objekti, jo personu pamatotās intereses ir plašāks jēdziens, kas aptver arī personu drošỉbu un veselību. Darba aizsardzības likuma 27. panta pirmā daļa noteic, ka darba devējs ir atbildīgs par nodarbināto drošību un veselību darbā. ${ }^{9}$ Tātad darba devējam, organizējot darbu, ir jānodrošina, ka darbinieks, veicot savus darba pienākumus atbilstoši darba devēja noteiktajai kārtībai, neapdraud savu veselību.

Reducējot DL 58. panta trešajā daļā noteiktos darbinieka atstādināšanas priekšnoteikumus, ir secināms, ka aizsargājamas ir darba devēja, darbinieku un trešo personu pamatotās intereses. Kā norādījusi LR Augstākā tiesa lietā SKC-461/2017 ${ }^{10}$, izšķirot jautājumu par atstādināšanas no darba likumību, tiesai jāizvērtē:

1) kādas ir tās darba devēja vai trešo personu pamatotās intereses, kuru apdraudējums būtu novēršams, un

2) jānodibina apstākḷi, kas apliecina kaitējuma iestāšanās iespējamību darbinieka neatstādināšanas gadījumā, proti, ka darbinieks, turpinādams pildīt darba pienākumus, var kaitēt darba devēja vai trešo personu pamatotām interesēm ${ }^{11}$.

Jēdziena "pamatotās intereses” visaptveroša atklāšana l̦auj piemērot darbinieka atstādināšanas institūtu pareizi un tiesiski. Kā norādījusi Augstākā tiesa 2015. gada 27. aprīḷa spriedumā lietā SKC-1942/2015, DL 58. panta trešajā daḷā lietotie jēdzieni "darba devēja vai trešo personu pamatotas intereses" ir atklāti (nenoteikti) juridiski jēdzieni jeb generālklauzulas. To satura konkretizēšana ir tiesas pienākums, atspogulojot spriedumā, kādi palīgavoti (ārpus tiesību normām esoši avoti, piemēram, morāle, sociālās vērtības, lietu dabiskā kārtība u. tml.) ir ņemti vērā. Ar jēèzienu "pamatotās intereses" nav jāsaprot ikkatras personu intereses, bet tikai ar likumu aizsargātas intereses. Ikvienai personai var būt dažādas intereses - ekonomiskās, politiskās, sociālās u. tml. -, taču darbinieka atstādināšanas pamats var būt tikai tādu interešu aizskārums, kuras aizsargā likums, t. i., pamatota interese ir tiesiski novērtējams labums (mantisks vai nemantisks), ko materiālās tiesību normas aizsargā. Tādējādi personu pamatotās intereses kā tiesisks labums (vācu val. Rechtsgut) aptver tiesību subjektu mantiskās tiesības, nemantiskās tiesības un nemantiskos labumus ${ }^{12}$. Šos tiesiskos labumus likums pasludina par neaizskaramiem. Arī Eiropas deliktu tiesību principi lieto līdzīgu apzīmējumu - tiesiski aizsargātā interese (2:101. pants: material or immaterial harm to a legally protected interest, angḷu val.). Ja notiek personas tiesiskā stāvokḷa (esošās situācijas) nevēlamas izmaiņas (tiesiska līdzsvara (miera) traucēšana ${ }^{13}$ ), vienmēr tiek ietekmēts tiesiskais labums. Pamatoto interešu kaitējuma konstatēšanai nav vajadzīgs, lai jau būtu noticis kaitējuma nodarī̌sanas fakts ${ }^{14}$, pietiek ar tiesību apdraudējumu, lai konstatētu

9 Darba aizsardzības likums: LV Likums. Latvijas Vēstnesis, 2001. 6. jūlijs, Nr. 105 (2492).

10 Latvijas Republikas Augstākās tiesas Civillietu departamenta 2017. gada 9. janvāra spriedums lietā C28410609 SKC-461/2017.

11 Latvijas Republikas Augstākās tiesas Civillietu departamenta 2016. gada 30. decembra spriedums lietā Nr. SKC-2064/2016, 8.1. p. Sk. arī LR Augstākās tiesas Tiesu prakses apkopojums darba lietās (tiesu prakse 2012. gada jūlijs-2017. gads), 2018, 18. lpp.

12 Torgāns K., Kārklinšs J., Bitāns A. Ligumu un deliktu problēmas Eiropas Savienībā un Latvijā. K. Torgāns (zin. red.). Rīga: Tiesu namu aǵentūra, 2017, 264. lpp.

13 Lange V. Atzī̌sanas prasība un mūsu Senāta judikatūra. Rīga, 1937, 14. lpp.

14 Kantors L. Atzī̌̌anas prasība Latvijas Civīlprocesā. Rīga: Grāmatrūpnieks, 1936, 58. lpp. 
pamatotu interešu aizskārumu (kaitējumu). DL 58. panta trešā daļa apzināti neoperē ar jēdzienu "tiesību aizskārums" kā priekšnoteikumu darbinieka atstādināšanai, jo tiesību aizskārums ir šaurāks jēdziens nekā pamatoto interešu aizskārums (kaitējums). Ne vienmēr situācijā, kur būs aizskartas intereses, būs uzreiz aizskartas arī konkrētas personas tiesības. Līdz ar to pamatoto interešu aizskārums (kaitējums) var izpausties divējādi:

1) kā esošu tiesību aizskārums;

2) kā likumīgo interešu aizskārums, kas vēl nav rezultējies tiesību aizskārumā.

Tomēr, vērtējot jautājumu par pamatoto interešu aizskārumu, nedrīkst ignorēt apstākli, ka DL kā pamatu darbinieka atstādināšanai nenosaka pamatoto interešu aizskāruma faktu, kas vērsts uz konstatējumu pagātnē, bet gan uz pamatoto interešu aizskārumu tagadnē un nākotnē. Uz to norāda DL 58. panta trešajā daḷā atrodamais formulējums "var kaitēt pamatotām interesēm". No minētā var izdarīt divus būtiskus secinājumus: a) darbinieka atstādināšana nevar būt sods par pārkāpumu, ko darbinieks jau ir veicis, un b) darba devējam ir jākonstatē, ka darbinieka neatstādināšana ar pietiekami lielu ticamības pakāpi var radìt tiesiski aizsargājamo labumu aizskārumu nākotnē. Tātad darba devējam ir jāmodelē uz nākotni vērsta situācija, kurā tiek vērtēts, vai darbinieka turpmāka strādāšana darba vietā radīs darba devēja vai trešo personu pamatoto interešu aizskārumu. Gadījumā, ja pārkāpums, par ko darba devējs vēlas darbinieku atstādināt, ir beidzies un tā turpināšanās nākotnē nav saskatāma, darba devējam, ja tas vēlas darbiniekam radīt noteiktas tiesiskās sekas, ir jāpiemēro citi darba tiesībās pastāvoši aizsardzības līdzekḷi, piemēram, disciplinārsods vai darba līguma uzteikums.

Robeža starp to, kad darbinieka pārkāpums var vai nevar radīt pamatoto interešu aizskārumu nākotnē, ir l̦oti izplūdusi un grūti nosakāma. Piemēram, kādā lietā Augstākās tiesas Senāts ${ }^{15}$ ir atzinis, ka atstādināšanas mērḳis ir ne tikai novērst iespējamo kaitējumu darbinieka vai trešās personas drošībai un veselībai vai darba devēja un trešās personas pamatotām interesēm, bet arī darba devējam dot iespēju atstādināšanas terminā veikt dienesta pārbaudi un, ja pastāv attiecīgs pamats, arī uzteikt darba lìgumu (sk. Senāta 2013. gada 23. janvāra spriedums, lieta Nr. SKC-103/2013). Minēto spriedumu nebūtu pareizi interpretēt tā, ka ikreiz, kad darba devējs vēlas veikt dienesta pārbaudi, ir pamats atstādināt darbinieku. Atstādināšana uz dienesta pārbaudes laiku ir iespējama tikai gadījumos, kad darbinieka neatstādināšanas gadījumā varētu zust iespēja noskaidrot svarīgus apstākḷus (veikt objektīvu dienesta pārbaudi), kas atainotu patiesībai atbilstošu faktisko situāciju un būtu iespējams atklāt vai novērst kaitējumu darba devēja vai trešo personu pamatotām interesēm. Turklāt šādam apsvērumam ir jābalstās nevis darba devēja subjektīvi iedomātos un teorētiski modelētos apstākḷos, bet gan objektīvi konstatējamos apstākḷ,os, piemēram, darbinieks sāk iznīcināt dokumentus, failus, saraksti u. c. pierādījumus, kas darba devējam nepieciešami izmeklēšanas veikšanai, vai arī darbinieks turpina iepriekš uzsāktu darba devēja vai trešo pamatoto interešu aizskārumu.

Tāpat, izvērtējot darbinieka atstādināšanas iespējamību, ir jāṇem vērā situācijas pēkšn,ais raksturs, darbinieka neatstādināšanas radītie iespējamie riski, log̣ika un dzīvē

15 Latvijas Republikas Augstākās tiesas Civillietu departamenta 2015. gada 14. maija spriedums lietā Nr. SKC-1892-15. 
gūtie novērojumi. Šajā saistībā Augstākās tiesas Senāts ir norādījis, ka DL 58. panta trešās dal̦as mērḳis ir nepiel̦aut situācijas, kad darbinieks, veicot darbu, var nodarīt kaitējumu sev vai trešajām personām, tādējādi l̦aujot darba devējam ātri reaǵēt uz šìm situācijām. Atstādināšana no darba nav pašmērķis, bet instruments iespējamo kaitīgo seku novēršanai. ${ }^{16} \mathrm{Lìdz}$ ar to, no vienas puses, darba devējam vienmēr ir jāizvērtē, vai informācija, kas ir viṇa rīcībā, ir radījusi objektīvu pamatu piemērot DL 58. panta trešajā daḷā noteikto aizsardzības līdzekli un, no otras puses, vai atstādināšana konkrētajā situācijā nav ar subjektīvu raksturu, kuras mērķis ir nevis pamatotu interešu aizsardzība, bet gan citu interešu aizsardzība. Piemēram, darbinieka atstādināšana nebūs tiesiska, ja tās vienīgais motīvs būs izolēt darbinieku no darba vides, preventīvi dodot signālu citiem darbiniekiem par pārkāpumu negatīvajām sekām, demonstrēt darba devēja izlēmību, saglabāt darba devēja kā vadītāja "seju" citu darbinieku priekšā u. tml. Tāpat darbinieka atstādināšanas pamatojums nevar būt vien apstāklis, ka darbinieks jau iepriekš ir veicis pārkāpumus, un tādējādi atstādināšana ir nākamais darba devēja stingrākas rīcības solis. Kā norādīts iepriekš, darbinieka atstādināšanas institūta mērḳis ir novērst darbinieka nelabvēlīgās darbības ietekmi uz nākotni. Taču gadījumā, ja šāda ietekme ir beigusies un nav saskatāma nākotnē, atstādināšanai trūkst pamatojuma. Atstādināšanas būtība ir darba devēja veiktā pašaizsardzība, tāpēc tai ir piemērojama pašaizsardzības ideja - pašaizsardzība ir jābeidz tur, kur beidzas tālāks apdraudējums. Tiesību doktrīnā ir atzīts, ka pašaizstāvība, cita starpā, izslēdz atbildību, ja ievēroti visi aizstāvēšanās tiesīguma nosacījumi:

a) apdraudejums ir nelikumīgs;

b) apdraudējums joprojām pastāv ${ }^{17}$.

\section{Darbinieka atstādināšanas rīkojuma saturs un forma}

Lai arī DL 58. panta sestajā daḷā ir noteikts, ka darba devējam ir pienākums izsniegt darbiniekam rakstveida rīkojumu, ar kuru darbinieks atstādināts no darba, no darba tiesību regulējuma un darbinieka aizsardzības principa izriet, ka, izdodot rìkojumu par darbinieka atstādināšanu, darba devējam ir jāizklāsta šādas atstādināšanas apstākḷi un tās pamatojums. Arī tiesību literatūrā ir norādīts: "Darba devējam ir pienākums darīt šos apstākḷus zināmus arī darbiniekam.” ${ }^{18}$ N̦emot vērā, ka DL 58. pantā nav atrodama norāde, ka šiem apstāklliem jābūt rakstveidā norādītiem pašā rīkojumā par atstādināšanu, secināms, ka par šiem apstākḷiem darbiniekam var darīt zināmu arī citos veidos, t. sk., pamatojums var izrietēt no vairāku dokumentu kopuma.

Vērtējot darbinieka atstādināšanas pamatojumu, darba devējam jāṇem vērā, ka gadījumā, ja darbinieka atstādināšana no darba ir bijusi nepamatota darba devēja vainas dẹl, darba devējam ir pienākums izmaksāt darbiniekam vidējo izpeḷnu par visu darba piespiedu kavējuma laiku, kā arī atlīdzināt ar atstādināšanu radušos zaudējumus

16 Latvijas Republikas Augstākās tiesas Senāta Civillietu departamenta spriedums lietā Nr. SKC766/2012. Tiesu prakses apkopojums darba tiesībās. Riga: LBAS, 2012, 189. lpp.

17 Krastiņš U., Liholaja V., Niedre A. Krimināllikuma zinātniski praktiskais komentārs. 1. sēj. Vispārīgā daļa. Riga: AFS, 2007, 116. lpp.

18 Darba likums ar komentāriem, 128. lpp. 
(DL 58. panta ceturtā daļa). Strīda gadījumā tieši darba devējam būs pienākums pierādìt, ka atstādināšanai no darba ir bijis objektīvs un pamatots iemesls. ${ }^{19}$

DL darbinieka atstādināšanu un tās procedūru neietekmē darbinieka specifiskais statuss, t. i., atstādināšanu var attiecināt uz jebkuru darba tiesībās izdalīto darbinieka speciālo statusu - nepilngadīgajiem, invalīdiem, grūtniecēm, sievietēm pēcdzemdību periodā, mātēm, kuras baro bērnu ar krūti, u. tml. Šāda kārtība ir noteikta lielākajā dalıā valstu, izṇemot, piemēram, Igauniju, kur darbinieka atstādināšanā darba devējam jāṇem vērā darbinieka specifiskais statuss. Piemēram, pēc Igaunijas Darbinieku disciplinārās atbildības likuma ${ }^{20} 20$. panta pirmās daļas, darba devējs nav tiesīgs atstādināt darbinieku, par atstādināšanas laiku vinam neizmaksājot darba samaksu, kurš atbilst šādām pazīmēm un darba devēja rīcībā par to ir apliecinošs dokuments:

1) grūtniecēm, mātēm, kurām ir bērns līdz trīs gadu vecumam, kā arī mātēm, kuras aprūpē bērnu invalīdu;

2) personām, kuras audzina bērnu invalīdu vai bērnu, kas jaunāks par trim gadiem, vai bērnu, kuram nav mātes;

3) bērna invalīda aizbildni vai aprūpētāju;

4) darbiniekam ir pienākums maksāt kompensāciju trešajai personai par tai nodarìto veselības kaitējumu vai uzturlīdzekḷus sakarā ar trešās personas nāvi.

Kā redzams, Igaunijas regulējums atškirias no Latvijas regulējuma un paredz lielāku darbinieku aizsardzību konkrētajā aspektā. Igaunijas regulējums nenozīmē, ka šādus darbiniekus - speciālos subjektus nav iespējams atstādināt no darba, bet gan ka atstādināšanas laikā darba devējam ir pienākums tiem izmaksāt atlīdzību. Šāda regulējuma mērḳis ir noteikts trešo personu interesēs, kuras gūst labumu no darbiniekam maksājamās atlīdzības. Vērtējot Igaunijas un Latvijas regulējumu, Latvijas likumdevējam nākotnē, iespējams, būs jāvērtē, vai DL nav nepieciešami grozījumi, kuri vairāk aizsargātu īpašā statusā esošus darbiniekus atstādināšanas periodā. Autoru ieskatā, pagaidām nav pamata grozìt Latvijas regulējumu, nnemot vērā, ka atstādināšana vienmēr notiek saistībā ar darbinieka pārkāpumu, tādējādi nebūtu pamata izdalìt atsevišķus speciālus subjektus, kuru prettiesiskā rīcība izraisa mazākas negatīvās sekas, nekā tad, ja šis darbinieks nebūtu īpašajā statusā. Turklāt Igaunijas regulējums būtībā risina darbinieka aizsardzības sociālos jautājumus uz darba devēja rēkina, kas primāri ir valsts, nevis privātpersonas uzdevums. Otrkārt, Igaunijā atškirīibā no Latvijas darbinieka atstādināšana ir uzskatāma par darbinieka disciplinārsoda veidu, tāpēc tās mērkisis ir citāds, un Igaunijas regulējuma automātiska pārṇemšana Latvijas tiesību sistēmā nebūtu pareiza.

Kā pamatoti secinājusi Augstākā tiesa, uz atstādināšanu nav attiecināmi DL 109. pantā norādītie uzteikuma aizliegumi un ierobežojumi, jo atstādināšana un uzteikums ir divi pilnīgi atšķirīgi tiesību institūti. Līdz ar to rīkojumu par atstādināšanu var izdot arī darbinieka darbnespējas laikā, un atstādināšanas gadījumā nav piemērojama analogija ar DL 109. pantu. ${ }^{21}$

19 Latvijas Republikas Augstākās tiesas Senāta Civillietu departamenta 2017. gada 9. janvāra spriedums lietā Nr. SKC-461/2017, 8. p.

20 Employees Disciplinary Liability Act. Pieejams: https://www.riigiteataja.ee/en/eli/ 510122013008/consolide [aplūkots 10.05.2019.].

21 Latvijas Republikas Augstākās tiesas Civillietu departamenta 2017. gada 9. janvāra spriedums lietā Nr. C28410609 SKC-461/2017. 


\section{Darbinieka atstādināšanas ilgums}

Lìdz 2006. gadam Darba likumā vispār nebija ietverts regulējums par piel̦aujamo atstādināšanas ilgumu. 2006. gadă ${ }^{22}$ DL 58. pants tika papildināts ar piekto daļu, kura darbinieka atstādināšanas ilgumu nosaka atkarībā no subjekta, kurš pieprasîjis atstādināšanu. Gadījumā, ja atstādināšanu pieprasa attiecīgi pilnvarota valsts institūcija, darbinieka atstādināšanas ilgums ir atkarīgs no šīs institūcijas, un likums neierobežo šādas atstādināšanas ilgumu. Savukārt, ja atstādināšanas subjekts ir darba devējs, maksimālais termiņš darbinieka atstādināšanai ir trīs mēneši (DL 58. panta piektā dala). Likumdevēja mērḳis, nosakot darbinieka atstādināšanai piel̦aujamo terminu, ir vērsts uz laika perioda pieškiršanu darba devējam, lai tas varētu novērst pamatoto interešu apdraudējumu. DL 58. pantā noteiktais maksimālais terminnš ir materiāltiesisks prekluzīvs termiņ̧̌̌, kuram iestājoties izbeidzas darba devēja tiesība nepielaist darbinieku pie darba, neizmaksājot par šo periodu darba samaksu. Kā norādījusi Augstākā tiesa ${ }^{23}$, atstādināšanas laikā darbinieks nesaņem darba samaksu, līdz ar to būtībā tiek atstāts bez iztikas līdzekḷiem, tādēl likumā ir noteikts šādas atstādināšanas laika ierobežojums, jo citādi darba devējam būtu tiesības atstādināt darbinieku no darba uz nenoteiktu laiku, kas ievērojami pasliktinātu darbinieka stāvokli. Atbilstoši DL 58. panta piektās daļas jēgai darba devējam dienesta pārbaude un lēmums par darba līguma uzteikumu jāpiennem trīs mēnešu laikā, un šì regulējuma mērḳis ir nepiel̦aut ilgstošu darbinieka atstāšanu bez darba samaksas un iztikas līdzekḷiem.

Jānorāda, ka darba devējam, lemjot par atstādināšanas termiṇu, ir jāizvērtē katrā situācijā konkrētie faktiskie apstākḷi kopsakarībā ar konkrēto atstādināšanas iemeslu, un atstādināšanas termiņam jābūt saprātīgam katrā individuālajā gadījumā, piemēram, gadijumā, ja darbinieks tiks atstādināts no darba tādēl, ka darbinieks atradies darba vietā reibuma stāvoklī vai veicis darbu reibuma stāvoklī, nebūs pamata piemērot atstādināšanu vairāku nedēllu garumā, savukārt, ja darbinieks rīkojies pretēji darba devēja interesēm, izdarīis kādu kolēgu vai citu personu apdraudējumu vai pamatoto interešu aizskārumu, šādos gadījumos apstākḷu noskaidrošana un izvērtěšana prasīs ilgāku laiku.

Citu valstu likumi nosaka atškirīgu atstādināšanas termiṇa regulējumu, piemēram, Igaunijā maksimālais darbinieka atstādināšanas termiņšs, neizmaksājot darba algu, var būt 10 dienas $^{24}$, bet ne biežāk kā trīs reizes gadā un ne ilgāk kā 20 kalendārās dienas gadā. Savukārt, pēc Lietuvas Darba kodeksa ${ }^{25}$ 49. panta, gadījumā, ja darbinieks tiek atstādināts pēc darba devēja iniciatīvas ar nolūku veikt izmeklēšanu par darbinieka pārkāpumiem, atstādināšanas maksimālais termiņš var būt 30 kalendārās dienas (un darbiniekam šajā laikā izmaksājama vidējā izpel̦na). Savukārt, ja atstādināšanu pieprasa pilnvarotās institūcijas, atstādināšanas terminş̌ var būt līdz trim mēnešiem (konkrēts termiņš tiek noteikts attiecīgās institūcijas pieprasījumā), un šādā gadījumā

22 Grozijumi Darba likumā: LV Likums. Latvijas Vēstnesis, 2006. 11. oktobris, Nr. 162 (3530).

23 Latvijas Republikas Augstākās tiesas 2013. gada 23. janvāra spriedums lietā SCK-103/2013.

24 Employees Disciplinary Liability Act. Art. 20. Pieejams: https://www.riigiteataja.ee/en/eli 510122013008/consolide [aplūkots 10.05.2019.].

25 Labour Code of the Republic of Lithuania. Pieejams: https://e-seimas.lrs.lt/portal/legalAct/lt/TAD/ da9eea30a61211e8aa33fe8f0fea665f?jfwid=-k3id7tf7e [aplūkots 10.05.2019.]. 
atstādināšanas laikā netiek izmaksāta darba samaksa. Šāda kārtība Lietuvā ir noteikta kopš 2017. gada vērienīgajiem grozījumiem Lietuvas Darba kodeksā, jo līdz tiem atstādināšanas termiņ̌̌ likumā vispār nebija noteikts, proti, tas bija atkarīgs no darba devēja ieskatiem, un strīdu gadījumā darba devējam bija jāspēj pamatot izvēlēto terminuu. Jāpiebilst, ka Lietuvas Darba kodeksa 49. panta ceturtajā dạ̦ā paredzētas darba devēja tiesības darbinieku ar vina piekrišanu atstādināšanas laikā norìkot citā darbā ( ja tas nenonāk pretrunā atstādināšanas mērkịm).

Lìdz 2017. gadam, kad tika veikti grozijumi Latvijas DL, papildinot 58. pantu ar septìto daḷu, tiesu praksē neskaidrības bija radījis jautājums, vai laikā, kad darbinieks ir atstādināts no darba, vinam iespējams izsniegt darba liguma uzteikumu, t. i., vai darba devējam ir jāpārtrauc atstādināšana, vai arī ir piel̦aujams atstādinātam darbiniekam izsniegt uzteikumu, nepārtraucot atstādināšanu ${ }^{26}$. Dažkārt tiesas bija interpretējušas atstādināšanas faktu kā vienu no uzteikuma ierobežojumiem DL 109. panta trešajā dạ̧ā noteikto uzteikumu ierobežojumu kontekstā (resp., minētā norma noteic arī, ka darba devējam nav tiesību uzteikt darba līgumu "laikā, kad darbinieks neveic darbu citu attaisnojošu iemeslu dẹl’"), un dažas tiesas atstādināšanu bija interpretējušas kā vienu no šiem attaisnojošajiem iemesliem. Tagad šis jautājums ir skaidri noregulēts, jo DL 58. panta septītā daļa paredz: "Darba devējam ir tiesības uzteikt darba līgumu laikā, kad darbinieks ir atstādināts no darba."27

Viena atstādināšanas gadijuma (iemesls un apstākḷi) maksimālais pieḷaujamais kopējais atstādināšanas termiņš ir trīs mēneši, resp., nav piel̦aujams pēc kāda laika darbinieku pielaist pie darba un tad atkal izdot rỉkojumu par atstādināšanu vēl uz laiku līdz trim mēnešiem, pamatojoties uz agrāk pastāvošiem apstākḷiem, kā tas dažkārt praksē kḷūdaini ticis izprasts.

Senākā tiesu praksē - 2009. gadā - Augstākā tiesa lietā Nr. SKC-891 $1^{28}$ secināja, ka darba devējs bija pamatoti atstādinājis darbinieku uz laiku līdz trīs mēnešiem, taču, beidzoties šim termiṇam, darba devējs izdeva jaunu rīkojumu par darbinieka atstādināšanu. Darba devējs to bija pamatojis ar apstākli, ka darbinieka pārkāpums ir būtisks, par ko var uzteikt darba tiesiskās attiecības, taču to neesot iespējams izdarīt, jo piekrišanu darba uzteikumam nedod darbinieka arodbiedrība. Vērtējot šo gadījumu, Augstākā tiesa norādīja, ka DL noteikts darbinieka tiesisko stāvokli pasliktinošu darba līgumu, koplīgumu, darba kārtības un darba devēja rīkojumu noteikumu aizliegums (DL 6. pants), tāpēc tiesa atzīst, ka ik pēc trīs mēnešiem izdoti rīkojumi par darbinieka atstādināšanu no darba, kā rezultātā darbinieks pēc būtības ir atstādināts no darba uz daudzkārt ilgāku laika posmu, nekā to piel̦auj likums, nav atzīstama par tiesisku rīcību. ${ }^{29}$

26 Likumprojekta “Grozījumi Darba likumā” sākotnējās ietekmes novērtējuma ziṇojums (anotācija): http://titania.saeima.lv/LIVS12/SaeimaLIVS12.nsf/0/A13521DACF3B0A70C2258154002231C C?OpenDocument\#b [aplūkots 03.05.2019.].

27 Grozijumi Darba likumā: LV Likums. Latvijas Vēstnesis, 2017. 2. augusts, Nr. 152 (5979).

28 Latvijas Republikas Augstākās tiesas Senāta Civillietu departamenta 2009. gada 14. oktobra spriedums lietā Nr. SKC-891/2009.

29 Latvijas Republikas Augstākās tiesas Senāta Civillietu departamenta 2009. gada 14. oktobra spriedums lietā Nr. SKC-891/2009. 13. p. 
Tomēr jāuzsver, ka 2009. gada lietā tiesas paustās tēzes nav absolūtas. Gadījumos, kad atstādinātais darbinieks ir arodbiedrības biedrs un darba devējs ir iecerējis izmantot tiesību uzteikt darba līgumu atstādināšanas laikā, noteiktās situācijās atstādināšanas termiņš var būt ilgāks. Kā norādījusi Augstākā tiesa 2013. gadā, atbilstoši 58. panta panta trešās daļas jēgai un mērķim panta regulējums ne vienmēr ir piemērojams gramatiski, proti, dažos gadijjumos ir jān, em vērā īpatnība, ka darba devējam objektīivi nav iespējams trīs mēnešu laikā izbeigt darba līgumu ar darbinieku arodbiedrības biedru, ja arodbiedrība darba līguma uzteikumam nav piekritusi, un tādā gadījumā darba devējam jācel prasība tiesā par darba tiesisko attiecību izbeigšanu (sk. DL 110. pantu). Ja piemērotu DL 58. panta piekto dalıu (t. i., par aizliegumu atstādināt darbinieku ilgāk par trim mēnešiem), iztulkojot to gramatiski, būtu jāatzīst, ka darba devējam pēc triju mēnešu atstādināšanas termiṇa notecējuma būtu jāatjauno darbinieks, kurš rīkojies prettiesiski un tādēl zaudējis darba devēja uzticību, un jālauj šādam darbiniekam pildīt darba pienākumus, izmaksājot viņam darba algu. Augstākā tiesa ir norādījusi, ka DL 58. panta piektās daḷas gramatiskā piemērošana šādos gadījumos ir pretēja tās jēgai, jo ar to tiek aizskarta darba devēja pamatotā interese nepiel̦aut darbinieka atrašanos darba vietā un darba pienākumu veikšanu konkrētajā gadijumā, kad konstatēts, ka tas var kaitēt darba devēja vai trešo personu pamatotām interesēm, un darba devējs no tā gribas neatkarīgu apstākḷ dēḷ nespēj minētajā tiesību normā noteiktajā atstādināšanas termin̄ā izbeigt darba tiesiskās attiecības. ${ }^{30} \breve{S}_{1}$ tēze balstās viedoklī, ka DL 58. panta piektajā daḷā ietvertais tiesiskais regulējums ir par plašu un neaptver tādu tiesiski nozìmīgu gadījumu, kad darba devējs ir spiests celt prasību tiesā, jo arodbiedrība nedod piekrišanu uzticību zaudējuša darbinieka atlaišanai, un tādā gadījumā uzticību zaudējušā darbinieka likumā noteikto atstādināšanas termiṇu objektīvu apstākḷu dēḷ nav iespējams ievērot, proti, konstatējams aizklāts likuma robs. Situācijā, kad sakarā ar darbinieka atstādināšanas pamatā esošajiem apstākḷiem celta prasība par darba līguma izbeigšanu, tiesām ir jāsašaurina DL 58. panta piektās dal̦as vārdiskais tvērums, neattiecinot to uz šādu situāciju, ierobežojot šīs normas piemērošanas jomu teleologiskās redukcijas ceḷā. Tiesību doktrīnā atzīts, ka teleoloǵiskā redukcija [..] pamatojas uz taisnīguma principu; tikai šeit ir runa [..] par nepieciešamību "atškirīgus gadijumus izšḳirt atškirīgi”. Citiem vārdiem, teleologiskās redukcijas priekšnoteikums ir secinājums, ka noteikts likumā regulēts dzives gadījums tiesiskā novērtējuma ziṇā tik būtiski atškiriras no pārējiem "patiesi domātajiem” dzīves gadijumiem, ka vienlīdzīga attieksme pret visiem šiem gadījumiem būtu "objektīvi neattaisnojama un patvalịga" ${ }^{2}$. Tādējādi teleologiskas redukcijas tiesiskais pamats atrodas taisnīguma prasībā atškirīgo nevērtēt vienādi, t. i., pamanīt un diferencēt atšķirīgas lietas.

Vērtējot darba strīdu 2013. gadā skatītajā lietā, Augstākā tiesa uzsvēra, ka tai ir zināms 2009. gada lietā Nr. SKC-891/2009 pašas Augstākās tiesas lemtais, tomēr 2013. gadā izskatāmajā lietā konstatētajiem apstākliem bija atšḳirīgas īpatnības, līdz ar to tiesa salīdzināja šìs atšķirības un, izvērtējot lietas faktiskos apstākḷus, izšķīra strīdu citādi. Par Augstākās tiesas lietā SCK-103/2013 konstatēto ir svarīgi piebilst, ka fakts

30 Latvijas Republikas Augstākās tiesas Civillietu departamenta 2013. gada 23. janvāra spriedums lietā Nr. SKC-103/2013 (C39065310).

31 Sk. Kalniņš E. Privāttiesību teorija un prakse. Raksti privāttiesībās. Rīga: Tiesu namu aǵentūra, 2005, 347.lpp. 
vien, ka atstādinātais darbinieks ir arodbiedrības biedrs, tāpēc viṇu nav iespējams DL noteiktā termiṇā atbrīvot no amata, nav vienīgais iemesls, lai izdarītu atkāpes no DL 58. pantā noteiktā maksimālā darbinieka atstādināšanas trīs mēnešu termiṇa. Kā uzsvērusi Augstākā tiesa vēl vienā - 2018. gada lietā SKC-462/2018 ${ }^{32}$-, SCK-103/2013 lietā darbinieka rīcībā bija konstatēts absolūts lojalitātes trūkums pret darba devēju, jo, būdams darbinieks, viņš bija rupji pārkāpis darījumu apstiprināšanas procedūras, ètikas un antikorupcijas principus, tādējādi rīkojies tī̌̌i, apzināti un viṇa darbības saistỉbā ar līguma restrukturizāciju bija vērstas uz personīgā labuma gūšanu, pakḷaujot darba devēju būtiskiem zaudējumiem un reputācijas riskiem. Tādējādi atkāpe no DL 58. panta piektajā daļā noteiktā atstādināšanas termiņa bija pamatota kā ar darbinieka amatu, tā piel̦auto pārkāpumu raksturu ${ }^{33}$. Apstāklis vien, ka atbildētājs ir arodbiedrības biedrs un attiecībā pret viņu nevarēja iegūt spēku darba devējas uzteikums bez arodbiedrības iepriekšēja akcepta, nevar radìt viņam nelabvēlīgākas sekas kā darbiniekam, kas nebūtu arodbiedrības biedrs. Uz to ir norādīts arī Augstākās tiesas 2014. gada 30. septembra spriedumā ${ }^{34}$, vēršot uzmanību, ka DL 58. panta piektajā daḷā ietvertās tiesību normas universāla sašaurināšana un sašaurinātā iztulkojuma attiecināšana uz visiem arodbiedrību biedriem visās situācijās neatkarīgi no konkrēta pārkāpuma specifikas var padarīt DL 110. panta noteikumus par arodbiedrību biedru aizsardzību praktiski nepiemērojamus, turklāt atņemot viņiem iztikas līdzekḷus uz visu tiesvedības laiku, neraugoties uz spēkā esošu darba līgumu. Tāpat kādā citā, 2018. gada 14. jūnija lietā Nr. SKC-462/2018 ${ }^{35}$ Senāta Civillietu departaments noraidīja darba devēja pozīciju, ka darba devējam bija tiesības atstādināt darbinieku uz ilgāku laiku nekā trīs mēneši. Šādu viedokli Augstākā tiesa pauda, lai gan konkrētajā lietā darbinieka rīcībā arī bija saskatāms lojalitātes trūkums un prettiesiskas darbības veikšana. N̦emot vērā iepriekš minēto, Senāta Civillietu departamenta 2013. gada 23. janvāra spriedumā lietā Nr. SKC-103/2013 izteiktā atziṇa par teleolog̣iskās redukcijas izmantošanu DL 58. panta piektās daḷas piemērošanā nav vispārināma ${ }^{36}$, un tās izmantošana ir izvērtējama katrā arodbiedrības biedra atstādināšanas gadījumā individuāli un uzskatāma par ārkārtēju izṇēmumu darbinieka atstādināšanas regulējuma piemērošanā. Autoru ieskatā, 2013. gada lietā SKC-103/2013 paustā atziṇa praksē būs piemērojama l̦oti retos gadījumos un darba devējiem nevajadzētu paļauties uz to, ka tiem ir tiesības atstādināt darbinieku ilgāk nekā uz trīs mēnešiem, pat tad, ja darbinieks ir rīkojies acīmredzami prettiesiski.

Neraugoties uz minēto, secināms, ka DL 58. panta piektajā daḷā noteiktais maksimālais trīs mēnešu darbinieka atstādināšanas termiņš ne vienmēr ir galīgs un absolūts, un, konstatējis l̦oti specifiskus faktiskos apstākḷus, darba devējs ir tiesīgs darbinieku atstādināt uz ilgāku laiku.

32 Latvijas Republikas Augstākās tiesas Senāta Civillietu departamenta 2018. gada 14. jūnija spriedums lietā Nr. SKC-462/2018. 11. p.

33 Ibid.

34 Latvijas Republikas Augstākās tiesas Civillietu departamenta 2014. gada 30. septembra spriedums lietā Nr. SKC-2562/2014.

35 Latvijas Republikas Augstākās tiesas Civillietu departamenta 2018. gada 14. jūnija spriedums lietā Nr. SKC-462/2018, 11.-12. lp.

36 Ibid., 11.p. 
Atšķirībā no Latvijas un Igaunijas Lietuvas Darba kodekss (50. pants) paredz darbinieka tiesības pašam atstatīties no darba. Šādas atstatī̌̌anās maksimālais termiņš ir noteikts trīs mēneši, taču ar niansi, ka darbiniekam par atstādināšanu ir rakstveidā jābrīdina darba devējs vismaz trīs darba dienas iepriekš. "Darbinieka īslaicīga atstatīšanās ir iespējama gadījumā, ja darba devējs vismaz divus mēnešus pēc kārtas nepilda likumā noteiktās saistības pret darbinieku, t. sk., neveic pilnu darba samaksu vismaz divus mēnešus pēc kārtas [...].” Vērtējot šo regulējumu Latvijas kontekstā, jāsecina - lai arī Latvijas DL nav paredzēts līdzīgs regulējums par darbinieka atstatīšanos kā Lietuvā, tomēr šādas darbinieka tiesības izriet no Civillikuma vispārējo līgumtiesību normu pamata. Saskaņā ar DL 28. panta trešo daļu, darba attiecībām ir piemērojami Civillikuma noteikumi, ciktāl tie nav pretrunā DL. Civillikuma 1591. pants noteic, ka gadijumā, “ja cel̦ prasību par divpusēja līguma izpildīšanu, prasītājam vai nu jāpiesola pienācīgs izpildījums, vai jāpierāda, ka viņš no savas puses līgumu jau izpildījis. Pretējā gadījumā pret vin,u var celt līguma neizpildīšanas ierunu, ja vien no pašas līgumiskās attiecības rakstura neizriet, ka atbildētājam pienākas papriekš izpildīt.” N̦emot vērā, ka darba līgums ir divpusējs līgums, darba devēja un darbinieka attiecībām ir piemērojams Civillikuma 1591. pants, kas nozīmē, ka gadījumā, ja darba devējs nepilda darba līguma noteikumus, piemēram, nemaksā darba algu, taču pieprasa darbiniekam turpināt veikt darbu, darbinieks ir tiesīgs aizturēt savu saistību izpildijumu, tātad - nepildìt darbu, lìdz darba devējs neizpilda savas saistības.

\section{Kopsavilkums}

1. Atstādināšana no darba atbilstoši DL 58. pantam var būt gan darba devēja tiesība, gan pienākums (ja to pieprasa normatīvajos aktos noteikta institūcija). Atstādināšana kā darba devēja tiesība ir darba devējam piemītoša subjektīva tiesība, kura pastāv uz objektīvo tiesību pamata un kuras izlietošana ir atkarīga no subjekta paša gribas.

2. Darbinieka atstādināšana notiek ar vienpusēju darba devēja gribas izteikumu (rīkojumu), tādējādi atstādināšana ir darba devēja konstitutīvo subjektīvo tiesību îstenošana, saskan̄ā ar kuru vienpusējā kārtā notiek esošā tiesiskā stāvokḷa izmaiṇas.

3. Latvijas praksē atstādināšana dažkārt kḷūdaini tiek asociēta ar sodīšanas funkciju, taču atstādināšana ir darba devēja rīcībā esošs preventīvs līdzeklis iespējama interešu apdraudējuma novēršanai. Baltijas valstīs šajā jautājumā nav vienotas nostājas, jo Igaunijā atstādināšana tiek regulēta kā disciplināratbildības veids.

4. DL 58. panta trešajā daḷā lietotie jēdzieni "darba devēja vai trešo personu pamatotas intereses" ir generālklauzulas. Ar jēdzienu "pamatotās intereses" nav jāsaprot ikkatras personu intereses, bet tikai ar likumu aizsargātas intereses, resp., darbinieka atstādināšanas pamats var būt tikai tādu interešu aizskārums, kuras aizsargā likums, t. i., pamatota interese ir tiesiski novērtējams labums (mantisks vai nemantisks), ko aizsargā materiālās tiesību normas. Pamatoto interešu kaitējuma konstatēšanai nav vajadzīgs, lai jau būtu notikusi kaitējuma nodarīšana, pietiek ar tiesību apdraudējumu, lai konstatētu pamatotu interešu aizskārumu (kaitējumu). 
5. Atstādināšana uz dienesta pārbaudes laiku ir iespējama tikai gadijjumos, kad darbinieka neatstādināšanas gadījumā varētu zust iespēja noskaidrot svarīgus apstākḷus (veikt objektīvu dienesta pārbaudi), kas atainotu patiesībai atbilstošu faktisko situāciju un būtu iespējams atklāt vai novērst kaitējumu darba devēja vai trešo personu pamatotām interesēm. Šādam apsvērumam ir jābalstās nevis darba devēja subjektīvi iedomātos un teorētiski modelētos apstākḷos, bet gan objektīvi konstatējamos apstākḷos.

6. Latvijā, līdzīgi kā vairākumā valstu, atstādināšana attiecināma arī uz darbinieku grupām, kuras darba tiesībās bauda īpašu aizsardzību (t. i., nepilngadīgie, invalīdi, grūtnieces, sievietes pēcdzemdību periodā, mātes, kuras baro bērnu ar krūti, u. tml.). Savukārt Igaunijā darba devējam jāṇem vērā darbinieka kā speciālās grupas statuss, jo šīm grupām piemērojams atšḳirīgs atstādināšanas regulējums.

\section{BIBLIOGRĀFIJA}

\section{Monogrāfijas un raksti}

1. Balodis K. Ievads Civiltiesībās. Rìga: Zvaigzne ABC, 2017.

2. Darba likums ar komentāriem. Zvērinātu advokātu birojs "BDO Zelmenis \& Liberte”. Rīga: LBAS, 2010.

3. Kalniņš E. Privāttiesību teorija un prakse. Raksti privāttiesībās. Rīga: Tiesu namu aǵentūra, 2005.

4. Kantors L. Atzīšanas prasība Latvijas Civīlprocesā. Rīga: Grāmatrūpnieks, 1936.

5. Krastiņš U., Liholaja V., Niedre A. Krimināllikuma zinātniski praktiskais komentārs. 1. sēj. Vispārīgā daḷa. Rìga: AFS, 2007.

6. Lange V. Atzīšanas prasība un mūsu Senāta judikatūra. Rīga, 1937.

7. Torgāns K., Kārkliņš J., Bitāns A. Līgumu un deliktu problēmas Eiropas Savienībā un Latvijā. K. Torgāns (zin. red.). Rīga: Tiesu namu aǵentūra, 2017.

\section{Normativie akti}

8. Darba likums: LV Likums. Latvijas Vēstnesis, 2001. 6. jūlijs, Nr. 105 (2492).

9. Grozījumi Darba likumā: LV Likums. Latvijas Vēstnesis, 2006. 11. oktobris, Nr. 162 (3530).

10. Grozījumi Darba likumā: LV Likums. Latvijas Vēstnesis, 2017. 2. augusts, Nr. 152 (5979).

11. Darba aizsardzības likums: LV Likums. Latvijas Vēstnesis, 2001. 6. jūlijs, Nr. 105 (2492).

12. Latvijas Republikas Civillikums: LV Likums. Valdības Vēstnesis, 1937. 26. februāris, Nr. 46.

13. Kriminālprocesā un administratīvo pārkāpumu lietvedībā nodarītā kaitējuma atlīdzināšanas likums: LV Likums. Latvijas Vēstnesis, 2017. 19. decembris, Nr. 252 (6079).

14. Employees Disciplinary Liability Act. Pieejams: https://www.riigiteataja.ee/en/eli/ 510122013008/consolide [aplūkots 10.05.2019.].

15. Labour Code of the Republic of Lithuania. Pieejams: https://e-seimas.lrs.lt/portal/legalAct/lt/ $\mathrm{TAD} /$ da9eea30a61211e8aa33fe8fofea665f?jfwid=-k3id7tf7e [aplūkots 10.05.2019.]. 


\section{Juridiskā prakse}

16. Latvijas Republikas Augstākās tiesas Senāta Civillietu departamenta 2009. gada 14. oktobra spriedums lietā Nr. SKC-891/2009.

17. Latvijas Republikas Augstākās tiesas Senāta Civillietu departamenta 2010. gada 27. oktobra spriedums lietā Nr. SKC-816/2010.

18. Latvijas Republikas Augstākās tiesas Senāta Civillietu departamenta 2012. gada 23. maija spriedums lietā Nr. SKC-766/2012.

19. Latvijas Republikas Augstākās tiesas Civillietu departamenta 2013. gada 23. janvāra spriedums lietā Nr. SKC-103/2013.

20. Latvijas Republikas Augstākās tiesas Civillietu departamenta 2014. gada 30. septembra spriedums lietā Nr. SKC-2562/2014.

21. Latvijas Republikas Augstākās tiesas Civillietu departamenta 2014. gada 19. novembra spriedums lietā Nr. SKC-2712-14.

22. Latvijas Republikas Augstākās tiesas Civillietu departamenta 2015. gada 14. maija spriedums lietā Nr. SKC-1892-15.

23. Latvijas Republikas Augstākās tiesas Civillietu departamenta 2016. gada 30. decembra spriedums lietā Nr. SKC-2064/2016.

24. Latvijas Republikas Augstākās tiesas Civillietu departamenta 2017. gada 9. janvāra spriedums lietā Nr. SKC-461/2017.

25. Latvijas Republikas Augstākās tiesas Senāta Civillietu departamenta 2018. gada 14. jūnija spriedums lietā Nr. SKC-462/2018.

26. Tiesu prakses apkopojums darba tiesībās. Rīga: Latvijas Brīvo arodbiedrību savienība, 2012.

27. Latvijas Republikas Augstākā tiesa Tiesu prakses apkopojums darba lietās (tiesu prakse 2012. gada jūlijs-2017. gads). Rìga, 2018.

\section{Citi prakses materiāli}

28. Likumprojekta "Grozījumi Darba likumā" sākotnējās ietekmes novērtējuma ziṇojums (anotācija): http://titania.saeima.lv/LIVS12/SaeimaLIVS12.nsf/0/A13521DACF3B0A70C2258 154002231CC?OpenDocument\#b [aplūkots 03.05.2019.]. 